\title{
Adverse effects of pre-pregnancy maternal underweight on pregnancy and perinatal outcomes in a freeze-all policy
}

\author{
Shengluan Tang, Jialyu Huang, Jiaying Lin and Yanping Kuang*
}

\begin{abstract}
Background: Underweight and overweight may affect reproduction and interfere with treatment of infertility. In the present retrospective analysis, we sought to evaluate the effect of low body mass index (BMI) on pregnancy and perinatal outcomes in frozen-thawed embryo transfer (FET) cycles.

Methods: This study involved 8755 FET cycles in a single IVF center during the period from January 2009 to December 2018. Both pregnancy and perinatal outcomes were assessed in women who were underweight, normal weight, and overweight as defined based on a respective $\mathrm{BMl}<18.5 \mathrm{~kg} / \mathrm{m}^{2}, \geq 18.5 \mathrm{BMl}<24.9 \mathrm{~kg} / \mathrm{m}^{2}$, and BMl $\geq 25$ $\mathrm{kg} / \mathrm{m}^{2}$.

Results: Being underweight was linked to reduced implantation rates as compared to a normal weight (33.56\% vs. 37.26\%). Similarly, when comparing outcomes in underweight women to those in normal weight women, rates of clinical pregnancy ( $48.14 \%$ vs. $53.85 \%)$ and ongoing pregnancy ( $43.04 \%$ vs. $50.47 \%)$ were reduced. Rates of miscarriage were markedly reduced in the normal weight group relative to the overweight group (10.73\% vs. 13.37\%). Perinatal outcomes were largely comparable for all groups, with the exception of very low birth weight rates (normal weight:0.58\% vs. overweight: $2.03 \%$ ), very small for gestational age rates (normal weight:1.31\% vs. overweight:3.55\%) and very preterm delivery rates (normal weight:0.82\% vs. overweight: $2.03 \%$ ), which were significantly elevated for overweight mothers.
\end{abstract}

Conclusions: These results indicate that being underweight is linked to negative pregnancy outcomes when undergoing FET-based IVF.

Keywords: Underweight, Overweight, Frozen embryo transfer, Pregnancy outcomes, Perinatal outcomes

\section{Background}

Reproductive outcomes have been shown to be linked to maternal weight in a wide variety of studies. For example, women who are either underweight or overweight/obese have higher rates of anovulatory infertility [1]. Indeed, there are many studies indicating that obesity adversely affects fertility [2, 3], the effectiveness of

\footnotetext{
*Correspondence: kuang_yp9h@126.com

Department of Assisted Reproduction, Shanghai Ninth People's Hospital, Shanghai Jiao Tong University School of Medicine, 639 Zhizaoju Rd, Shanghai 200011, China
}

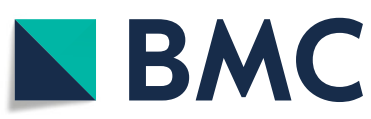

(c) The Author(s). 2021 Open Access This article is licensed under a Creative Commons Attribution 4.0 International License, which permits use, sharing, adaptation, distribution and reproduction in any medium or format, as long as you give appropriate credit to the original author(s) and the source, provide a link to the Creative Commons licence, and indicate if changes were made. The images or other third party material in this article are included in the article's Creative Commons licence, unless indicated otherwise in a credit line to the material. If material is not included in the article's Creative Commons licence and your intended use is not permitted by statutory regulation or exceeds the permitted use, you will need to obtain permission directly from the copyright holder. To view a copy of this licence, visit http://creativecommons.org/licenses/by/4.0/ The Creative Commons Public Domain Dedication waiver (http://creativecommons.org/publicdomain/zero/1.0/) applies to the data made available in this article, unless otherwise stated in a credit line to the data. \section{assisted reproductive technology (ART) $[4,5]$, and preg-} little data with respect to how being underweight (body mass index $[\mathrm{BMI}]<18.5 \mathrm{~kg} / \mathrm{m}^{2}$ ) influences these same outcomes. Studies that have been published provide inconsistent findings, potentially as a consequence of variability in methodology, inclusion criteria, BMI definitions, outcomes assessed, or adjustments based on confounding variables [8]. In addition, while some studies of IVF report on multiple treatment outcomes, some report only upon the first treatment cycle so as to prevent 
analytical complications stemming from the analysis of multiple, non-independent cycles in a given individual [9].

Frozen-embryo transfer is a technique that is now being widely applied, with more and more frozen cycles being employed worldwide [10]. This strategy depends upon the initial cryopreservation of all embryos, which are, upon thawing, transferred in a cyclical manner into more appropriate and physiologically relevant conditions [11]. Some reports suggest that pregnancies achieved via FET have lower rates of adverse complications, such as antepartum hemorrhaging, and superior infant outcomes, such as a decreased rates of perinatal death and increased weight at birth [10].

To the best of our knowledge, no studies have investigated the possible relationship between low BMI and neonatal outcomes in FET cycles. Previously published data exclusively focused on fresh IVF cycles, without ruling out the possibility of adverse fetal growth caused by a hyperestrogenic milieu [12]. This study therefore sought to explore how maternal low BMI influences pregnancy and neonatal outcomes in women undergoing FET.

\section{Methods}

\section{Study subjects}

This was a retrospective cohort study conducted between January 2009 and December 2018 at the Department of Assisted Reproduction of the Ninth People's Hospital of Shanghai Jiao Tong University School of Medicine. Any women during this time scheduled to complete their initial FET cycle were enrolled to participate based on the following inclusion criteria: 1) 20-40 years old; 2) cycle day $3 \mathrm{FSH}<10 \mathrm{IU} / \mathrm{l}$. Patients were excluded if they met the following criteria: 1) Ovarian failure as determined by a lack of antral follicles upon ultrasound assessment, FSH $>10 \mathrm{IU} / \mathrm{L}$; 2) Prior diagnosis of diabetes or hypertension; 3) Recurrent miscarriage or $\geq 2$ spontaneous abortions; 4) Chromosomal abnormalities in either spouse; 5) Endocrine abnormalities (polycystic ovarian syndrome, hyperprolactinemia, abnormal thyroid function, etc.). Certain drugs and diseases that can cause underweight are excluded, including amphetamines, hyperthyroidism, Diabetes, Addison's disease, Sheehan syndrome, Chronic gastritis, Inflammatory bowel disease, Hepatitis, tuberculosis, malignant tumor and anorexia nervosa. This study was approved by the Ethics Committee (Institutional Review Board) of the Ninth People's Hospital of Shanghai. And the study was conducted according to the Declaration of Helsinki for medical research and informed consent was obtained. Patient demographic information and cycle parameters were recorded in our medical records system. Patient BMI was determined as follows: $\mathrm{BMI}=$ weight $/$ height $^{2}$ $\left(\mathrm{kg} / \mathrm{m}^{2}\right)$ during the initial patient consult. Based on these BMI results, patients were divided into three categories based on World Health Organization (WHO) criteria: < $18.5 \mathrm{~kg} / \mathrm{m}^{2}$ (underweight), $18.5-24.9 \mathrm{~kg} / \mathrm{m}^{2}$ (normal), $25.0-29.9 \mathrm{~kg} / \mathrm{m}^{2}$ (overweight). Patients with a BMI> 30 $\mathrm{kg} / \mathrm{m}^{2}$ were not included in this study of low body weight. The weight and height of the patient was measured in the initial IVF/ICSI cycle. The duration was $6.05 \pm 5.21$ months from the measurement to the pregnancy occurred.

\section{Endometrial preparation and frozen embryo transfer}

Our center adopts a freeze-all strategy, so patients will not undergo fresh embryo transfer until FET fails more than twice. Detailed descriptions of embryo culture, endometrial preparation, and embryonic transfer have been presented in our previous publications [13]. Embryos were assessed as a means of establishing blastomere numbers and morphology, and in order to determine embryonic disintegration levels based upon Cummins's criteria [14]. Those embryos deemed to be of high-quality (grade 1 or 2, 8-cell embryos) underwent vitrification in order to freeze them three days following the retrieval of the oocytes. Low quality embryos instead underwent extended culture until reaching a blastocyst stage, and on day 5-6 those morphologically normal blastocysts were also frozen.

\section{Outcomes}

Pregnancy outcomes assessed in this study included rates of implantation, clinical pregnancy, ongoing pregnancy, and live births/transfer cycle. Rates of implantation were determined based upon an ultrasound-mediated quantification of gestational sac numbers relative to numbers of embryos transferred. Clinical and ongoing pregnancy rates were determined on the basis of ultrasound-mediated gestational sac and fetal heartbeat detection at gestational week 7 and 12, respectively. Live births were determined based upon the delivery of at least one live child after gestational week 24 . We additionally recorded rates of early/late miscarriage (before gestational week 24), stillbirths, ectopic pregnancies, and terminations as a result of fetal developmental issues. Very preterm birth and preterm birth were defined as delivery before 32 and 37 gestation weeks, respectively. Very small for gestational age and small for gestational age were defined as birth weights < 3rd and $<10$ th percentiles in the reference group, respectively. Large for gestational age was defined as birth weights $>90$ th percentiles. Z-score was selected to estimate birth weight adjusted for gestational age and sex. The equation is: Z-score $=(x-\mu) / \sigma$, in which $x$ is the birth weight of a baby, $\mu$ is the mean birth weight for the same gestational age and sex, and $\sigma$ is the standard 
deviation for the same gestational age and sex. Birth weight percentiles and Z-scores were depended on birth weight reference percentiles for Chinese [15]. Congenital malformations were identified according to International Classification of Diseases Q codes (Q00-Q99) based on registered conditions and diseases [16].

\section{Statistical analysis}

SPSS v18.0 (SPSS Inc., IL, USA) was used for all analyses. For continuous variables, the normality was tested by the graphical use of histograms and Q-Q plots as well as the Shapiro-Wilk test. If data are normally distributed then they were presented as mean with standard deviation (SD), otherwise they were presented as median (min - max). Continuous variables were compared via one-way ANOVA, while categorical variables were compared via chi-squared tests. Logistic regressions were utilized to determined odds ratios (ORs) and associated 95\% confidence intervals (CIs) when comparing data between BMI groups. Models were adjusted for a range of possible confounding variables as follows: maternal age, infertility duration, endometrial thickness, embryo quality, number of embryos transferred, and embryo developmental stage. $P<0.05$ was the threshold of statistical significance.

\section{Results}

\section{Patient characteristics}

The baseline characteristics of the 8755 women enrolled in this study, divided into three BMI subgroups (underweight, normal weight, overweight), are outlined in Table 1.There were no significant between-group differences in age of embryo transfer, age of oocyte retrieval, duration of infertility, antral follicle number, infertility causes, type of infertility, endometrial thickness on transfer day, basal $\mathrm{P}$ level, or fertilization method $(P>$ 0.05 ) (Table 1). As found previously [17, 18], the basal FSH, LH, and E2 levels in the overweight group were significantly lower than those in the underweight and normal weight groups $(P<0.05)$. The use of artificial hormone replacement cycles was more common in the underweight $(24.71 \%)$ and overweight $(25.87 \%)$ groups compared with normal weight women $(22.04 \%)$. The proportion of patients undergoing natural cycles decreased with increasing BMI.

\section{Pregnancy outcomes}

Comparison of the pregnancy outcomes between the three BMI subgroups are presented in Table 2. The distribution of good quality embryos transfer was comparable between groups $(P>0.05)$. There were also no significant differences in the rates of multiple pregnancy, ectopic pregnancy, intrauterine pregnancy, or live birth between the underweight, normal weight and overweight groups $(\mathrm{P}>0.05)$. However, the implantation (underweight: $33.56 \%$ vs. normal weight: $37.26 \%$ vs. overweight: $35.48 \%$ ), clinical pregnancy (underweight: $48.14 \%$ vs. normal weight:53.85\% vs. overweight: $51.32 \%$ ), and ongoing pregnancy rates (underweight: $43.04 \%$ vs. normal weight: $50.47 \%$ vs. overweight: $46.45 \%$ ) were significantly higher in the normal weight group relative to the underweight group (Table 2). Moreover, the miscarriage rate (underweight: $12.64 \%$ vs. normal weight: $10.73 \%$ vs. overweight: $13.37 \%$ ) was significantly lower in normal weight group relative to in the overweight group.

\section{Perinatal outcomes}

Details of perinatal outcomes such as gestational age, Zscore, weight at birth, and sex are summarized in Table 3 . These outcomes were largely similar between these three groups, with the exception of rates of VLBW $(<1500 \mathrm{~g})$ (normal weight: $0.58 \%$ vs. overweight: $2.03 \%)$, very small for gestational age rates (normal weight:1.31\% vs. overweight:3.55\%) and VPTD (<32 weeks) (normal weight: $0.82 \%$ vs. overweight: $2.03 \%$ ), which were significantly higher for overweight group relative to normal weight group. Besides, the rate of cesarean section (under weight:60.91\% vs. normal weight: $65.42 \%$ vs. overweight: $76.65 \%$ ) was significantly higher for overweight group relative to other two groups.

\section{Congenital defects}

Based on International Classification of Diseases criteria, 98 live neonates (1.95\%) exhibited congenital defects (Table 4). These defects were evident in 20/707 (2.05\%) of infants from the underweight group, 66/3663 (1.80\%) from the normal weight group, and 12/662 (1.81\%) from the overweight group, with no significant differences between groups $(P>0.05)$. There were also no significant differences when infants were assessed based on singleton/multiple births or sex. The defects observed most frequently were those affecting the circulatory system (underweight: 1.56\%; normal weight: $0.98 \%$; overweight: $1.06 \%)$. Rates of specific defects or affected systems did also not differ significantly between groups.

\section{Logistic regression analysis of BMI-related pregnancy or perinatal outcomes}

We next conducted a multivariate logistic regression analysis to identify significant differences in pregnancy/ perinatal outcomes as a function of maternal BMI (Table 5). As shown, clinical pregnancy and ongoing pregnancy were significantly lower in the underweight group relative to the normal weight group. In addition, VPTD, VLBW and very small for gestational age were significantly higher in the overweight group relative to the normal weight group. 
Table 1 Baseline characteristics of all FET cycles

\begin{tabular}{|c|c|c|c|c|c|c|}
\hline Characteristic & $\begin{array}{l}\text { Underweight } \\
\left(<18.5 \mathrm{~kg} / \mathrm{m}^{2}\right. \\
N=1315)\end{array}$ & $\begin{array}{l}\text { Normal weight } \\
\left(18.5-24.9 \mathrm{~kg} / \mathrm{m}^{2}\right. \\
N=6230)\end{array}$ & $\begin{array}{l}\text { Overweight } \\
\left(\geq 25 \mathrm{~kg} / \mathrm{m}^{2}\right. \\
N=1210)\end{array}$ & $\begin{array}{l}\text { Underweight vs. } \\
\text { normal weight }\end{array}$ & $\begin{array}{l}\text { Overweight vs. } \\
\text { normal weight }\end{array}$ & $\begin{array}{l}\text { Overweight vs. } \\
\text { underweight }\end{array}$ \\
\hline $\begin{array}{l}\text { Age of embryo transfer (years), mean } \\
\text { (SD), }\end{array}$ & $33.63 \pm 3.51$ & $33.84 \pm 3.79$ & $33.69 \pm 3.65$ & 0.065 & 0.205 & 0.674 \\
\hline $\begin{array}{l}\text { Age of oocyte retrieval (years),mean } \\
\text { (SD), }\end{array}$ & $33.12 \pm 3.43$ & $33.29 \pm 3.85$ & $33.17 \pm 3.57$ & 0.138 & 0.316 & 0.720 \\
\hline Duration of infertility (years), mean (SD), & $3.57 \pm 1.28$ & $3.62 \pm 1.35$ & $3.69 \pm 1.62$ & 0.472 & 0.352 & 0.219 \\
\hline BMl of women, mean (SD), & $17.53 \pm 3.07$ & $21.61 \pm 1.73$ & $26.37 \pm 1.88$ & $<0.001$ & $<0.001$ & $<0.001$ \\
\hline Antral follicle count $(n)$,mean (SD), & $12.41 \pm 5.64$ & $12.72 \pm 5.68$ & $12.67 \pm 6.07$ & 0.072 & 0.782 & 0.265 \\
\hline Infertility causes, $n(\%)$ & & & & 0.291 & 0.988 & 0.494 \\
\hline Tubal infertility & $790(60.09 \%)$ & 3917 (62.87\%) & $762(62.98 \%)$ & & & \\
\hline Male factor infertility & $83(6.32 \%)$ & $373(5.98 \%)$ & $75(6.18 \%)$ & & & \\
\hline Unexplained infertiltiy & $70(5.31 \%)$ & $318(5.11 \%)$ & $60(4.98 \%)$ & & & \\
\hline Combined* & $372(28.28 \%)$ & $1622(26.04 \%)$ & $313(25.86 \%)$ & & & \\
\hline Basal FSH (mIU/mL),median (min-max) & $5.77(0.18-9.99)$ & $5.55(0.63-9.97)$ & $5.43(0.43-9.99)$ & $<0.001$ & 0.008 & $<0.001$ \\
\hline Basal LH (mlU/mL),median (min-max) & $\begin{array}{l}5.02(0.13- \\
17.96)\end{array}$ & $4.63(0.15-18.32)$ & $\begin{array}{l}3.74(0.42- \\
16.22)\end{array}$ & $<0.001$ & $<0.001$ & $<0.001$ \\
\hline Basal E2 (pg/mL),median (min-max) & $\begin{array}{l}35.00(10.00- \\
86.00)\end{array}$ & $\begin{array}{l}33.00(10.00- \\
88.00)\end{array}$ & $\begin{array}{l}32.00(10.00- \\
92.00)\end{array}$ & 0.017 & 0.154 & 0.009 \\
\hline Basal P (ng/mL),median (min-max) & $0.30(0.10-0.90)$ & $0.30(0.10-0.80)$ & $0.30(0.10-0.90)$ & 0.991 & 0.126 & 0.326 \\
\hline Type of infertility, $n(\%)$ & & & & 0.083 & 0.295 & 0.069 \\
\hline Primary & $840(63.89 \%)$ & 4107 (65.93\%) & 808 (66.79\%) & & & \\
\hline Secondary & $475(36.11 \%)$ & $2123(34.07 \%)$ & $402(33.21 \%)$ & & & \\
\hline Type of FET cycle, $n$ (\%) & & & & 0.031 & $<0.001$ & $<0.001$ \\
\hline HRT & $325(24.71 \%)$ & $1373(22.04 \%)$ & $313(25.87 \%)$ & & & \\
\hline Natural cycle & $290(22.05 \%)$ & 1303 (20.91\%) & 169 (13.97\%) & & & \\
\hline Ovarian stimulation & $700(53.24 \%)$ & $3554(57.05 \%)$ & $728(60.16 \%)$ & & & \\
\hline $\begin{array}{l}\text { Endometrial thickness on transfer day, } \\
\text { mean (SD) }\end{array}$ & $10.31 \pm 3.32$ & $10.47 \pm 2.92$ & $10.44 \pm 2.24$ & 0.078 & 0.686 & 0.253 \\
\hline Fertilization method, $n(\%)$ & & & & 0.088 & 0.245 & 0.112 \\
\hline IVF & $838(63.73 \%)$ & $3860(61.96 \%)$ & 743 (61.41\%) & & & \\
\hline ICSI & $326(24.79 \%)$ & $1720(27.61 \%)$ & $356(29.42 \%)$ & & & \\
\hline Half IVF+half ICSI & $151(11.48 \%)$ & $650(10.43 \%)$ & $111(9.17 \%)$ & & & \\
\hline
\end{tabular}

Combined* was defined as two or more infertile causes mentioned above

\section{Discussion}

This is the first large-scale study assessing the effects of BMI on pregnancy/ perinatal outcomes following FET in a Chinese cohort. Our results reveal that rates of implantation and ongoing/clinical pregnancy were significantly lower when mothers were underweight. When mothers were instead overweight, this was associated with a higher rate of very low birth weight or very preterm delivery. There was also a non-significant trend towards lower live birth rate in both the overweight and underweight groups relative to the normal weight group. There were no other significant effects of maternal BMI on perinatal characteristics or rates of congenital defects.
While previous studies have found that obesity can be linked to poor IVF outcomes, our results provide new insight into the negative effects of being underweight on FET outcomes.

Many past assessments of how being underweight influences pregnancy outcomes have produced inconsistent results. For example, Cai et al. found that in a study of over 4000 women undergoing ovarian stimulation via the agonist or antagonist protocols, being underweight was linked to a lower rate of live births (low BMI:50\% vs. normal BMI:52.4\%, $P=0.198$ ) but this trend was not significant, whereas abortion rates were significantly increased in those with low BMI relative to those with a 
Table 2 Reproductive outcomes following transferring blastocyst stage embryo

\begin{tabular}{|c|c|c|c|c|c|c|}
\hline Characteristics & $\begin{array}{l}\text { Underweight } \\
\left(<18.5 \mathrm{~kg} / \mathrm{m}^{2}\right. \\
N=1315)\end{array}$ & $\begin{array}{l}\text { Normal weight } \\
\left(18.5-24.9 \mathrm{~kg} / \mathrm{m}^{2}\right. \\
N=6230)\end{array}$ & $\begin{array}{l}\text { Overweight } \\
\left(\geq 25 \mathrm{~kg} / \mathrm{m}^{2}\right. \\
N=1210)\end{array}$ & $\begin{array}{l}\text { Underweight vs. } \\
\text { normal weight }\end{array}$ & $\begin{array}{l}\text { Overweight vs. } \\
\text { normal weight }\end{array}$ & $\begin{array}{l}\text { Overweight vs. } \\
\text { underweight }\end{array}$ \\
\hline Number of FET & 1315 & 6230 & 1210 & & & \\
\hline $\begin{array}{l}\text { Number of viable embryos after } \\
\text { thawed }\end{array}$ & 2390 & 11,440 & 2193 & & & \\
\hline Embryo quality & & & & 0.296 & 0.171 & 0.402 \\
\hline High-quality embryos & $2321(97.11 \%)$ & 11,135 (97.33\%) & 2126 (96.95\%) & & & \\
\hline Low-quality embryos & $69(2.89 \%)$ & $305(2.67 \%)$ & 67 (3.05\%) & & & \\
\hline Clinical pregnancy rate per transfer,\%(n) & $\begin{array}{l}48.14 \%(633 / \\
1315)\end{array}$ & $\begin{array}{l}53.85 \%(3355 / \\
6230)\end{array}$ & $\begin{array}{l}51.32 \%(621 / \\
1210)\end{array}$ & 0.018 & 0.193 & 0.186 \\
\hline Implantation rate,\%(n) & $\begin{array}{l}33.56 \%(802 / \\
2390)\end{array}$ & $\begin{array}{l}37.26 \%(4263 / \\
11440)\end{array}$ & $\begin{array}{l}35.48 \%(778 / \\
2193)\end{array}$ & 0.019 & 0.145 & 0.178 \\
\hline Miscarriage rate,\%(n) & $12.64 \%(80 / 633)$ & $10.73 \%(360 / 3355)$ & $13.37 \%(83 / 621)$ & 0.119 & $<0.001$ & 0.401 \\
\hline Multiple pregnancy rate,\%(n) & $\begin{array}{l}26.69 \%(169 / \\
633)\end{array}$ & $27.06 \%(908 / 3355)$ & $\begin{array}{l}25.28 \%(157 / \\
621)\end{array}$ & 0.464 & 0.257 & 0.354 \\
\hline Ectopic pregnancy rate, $\%(n)$ & $2.59 \%(17 / 654)$ & $2.41 \%(81 / 3364)$ & $2.04 \%(13 / 637)$ & 0.431 & 0.352 & 0.321 \\
\hline $\begin{array}{l}\text { Intrauterine and ectopic pregnancy } \\
\text { rate, } \%(n)\end{array}$ & $0.61 \%(4 / 654)$ & $0.83 \%(28 / 3364)$ & $0.47 \%(3 / 637)$ & 0.387 & 0.251 & 0.515 \\
\hline Ongoing pregnancy rate,\%(n) & $\begin{array}{l}43.04 \%(566 / \\
1315)\end{array}$ & $\begin{array}{l}50.47 \%(3144 / \\
6230)\end{array}$ & $\begin{array}{l}46.45 \%(562 / \\
1210)\end{array}$ & 0.002 & 0.071 & 0.152 \\
\hline Live birth rate,\%(n) & $\begin{array}{l}42.05 \%(553 / \\
1315)\end{array}$ & $\begin{array}{l}45.97 \%(2864 / \\
6230)\end{array}$ & $\begin{array}{l}43.64 \%(528 / \\
1210)\end{array}$ & 0.057 & 0.187 & 0.319 \\
\hline
\end{tabular}

normal BMI (13.8\% vs. $10.7 \%, P=0.049)$ [19]. A separate Danish study of 487 women undergoing frozen or fresh embryo transfer, however, detected no differences in rates of ongoing or ectopic pregnancy, miscarriage, or live births in women who were underweight [20]. A separate study of 332 women without PCOS beginning an initial IVF cycle with the downregulation, antagonist, or microflare protocols observed no effect of low body weight on rates of implantation, clinical pregnancy, or ongoing pregnancy [4]. These previous studies had marked differences in methodology, using fresh or frozen embryos and adjusting for different risk factors, thus potentially explaining these divergent results. Lower fertility rates in underweight women can also be a function of lower levels of leptin [21], which is a hormone mainly produced by fat tissue [22]. The receptor for leptin is known to be present within the secretory endometrium, potentially regulating uterine angiogenesis and implantation $[23,24]$.

Preterm birth and low birth weight are, in that order, the most prominent causes of death among neonates [25]. In past work assessing outcomes of spontaneous pregnancies among underweight women, results have suggested that lower maternal BMI is linked to higher rates of both of these negative outcomes [26, 27], with similar findings for assessments of women undergoing fresh IVF cycles [18]. This was in contrast to our results, which suggested largely similar perinatal outcomes among women with a lower BMI relative to normal BMI group. Indeed, past work of singleton children born following FET has suggested lower rates of both preterm birth and low birth rate relative to children born as a result of either fresh embryo transfer or spontaneous conception [28]. This, coupled with our results, suggests the possibility that the freezing of embryos may improve outcomes, and that this is particularly true in the case of mothers who are underweight. One possibility explaining these better FET outcomes may be that the freezethaw process selects for higher quality embryos, as only these are able to survive this process, and that these higher quality embryos may thereafter be linked to lower rates of LBW and preterm birth $[29,30]$.

Unlike studies of underweight mothers, overweight mothers were found to have a higher risk of miscarriage, in addition to higher very low birth weight $(<1500 \mathrm{~g})$, very small for gestational age ( $<3$ rd percentiles) and very preterm delivery $(<32$ weeks) risks. This was consistent with other past studies, which have found being overweight to be linked to reduced fertility [2], and to higher miscarriage rates and obstetric risk [31, 32]. Abnormally high body weight is known to be linked to changes in overall carbohydrate metabolism and increasing resistance to insulin [33], which is often associated with inflammation mediated by interleukin (IL)-1ß, IL-6, and tumor necrosis factor a [34, 35]. Stress as a consequence of physical infections or psychological factors can drive 
Table 3 Perinatal outcome stratified by BMI

\begin{tabular}{|c|c|c|c|c|c|c|}
\hline \multirow[t]{2}{*}{ Birth characteristic } & \multicolumn{3}{|l|}{ Singleton births } & \multirow{2}{*}{$\begin{array}{l}\text { Underweight } \\
\text { vs. normal } \\
\text { weight }\end{array}$} & \multirow{2}{*}{$\begin{array}{l}\text { Overweight } \\
\text { vs. normal } \\
\text { weight }\end{array}$} & \multirow{2}{*}{$\begin{array}{l}\text { Overweight } \\
\text { vs. } \\
\text { underweight }\end{array}$} \\
\hline & $\begin{array}{l}\text { Underweight }(<18.5 \\
\left.\mathrm{kg} / \mathrm{m}^{2} \mathrm{~N}=399\right)\end{array}$ & $\begin{array}{l}\text { Normal weight (18.5-24.9 } \\
\left.\mathrm{kg} / \mathrm{m}^{2} \mathrm{~N}=2062\right)\end{array}$ & $\begin{array}{l}\text { Overweight ( } \geq 25 \mathrm{~kg} / \\
\left.\mathrm{m}^{2} \mathrm{~N}=394\right)\end{array}$ & & & \\
\hline \multicolumn{7}{|c|}{ Birth weight(g),\%(n) } \\
\hline$<1500 \mathrm{~g}$ & $0.75 \%(3 / 399)$ & $0.58 \%(12 / 2062)$ & $2.03 \%(8 / 394)$ & 0.451 & 0.009 & 0.112 \\
\hline $1500-2499 \mathrm{~g}$ & $3.51 \%(14 / 399)$ & $3.44 \%(71 / 2062)$ & $4.82 \%(19 / 394)$ & 0.522 & 0.129 & 0.239 \\
\hline$\geq 2500 \mathrm{~g}$ & $95.74 \%(382 / 399)$ & 95.98\%(1979/2062) & $93.15 \%(367 / 394)$ & 0.503 & 0.368 & 0.414 \\
\hline Z-score & $0.04 \pm 0.96$ & $-0.03 \pm 1.04$ & $0.02 \pm 1.02$ & 0.213 & 0.381 & 0.776 \\
\hline $\begin{array}{l}\text { Very small for } \\
\text { gestational age }\end{array}$ & 1.75\%(7/399) & $1.31 \%(27 / 2062)$ & $3.55 \%(14 / 394)$ & 0.486 & 0.001 & 0.115 \\
\hline $\begin{array}{l}\text { Small for } \\
\text { gestational age }\end{array}$ & $3.51 \%(14 / 399)$ & $3.35 \%(69 / 2062)$ & $3.81 \%(15 / 394)$ & 0.869 & 0.645 & 0.823 \\
\hline $\begin{array}{l}\text { Adequate for } \\
\text { gestational age }\end{array}$ & $85.96 \%(343 / 399)$ & $86.42 \%(1782 / 2062)$ & $83.76 \%(330 / 394)$ & 0.808 & 0.163 & 0.386 \\
\hline $\begin{array}{l}\text { Large for } \\
\text { gestational age }\end{array}$ & 8.77\%(35/399) & $8.92 \%(184 / 2062)$ & $8.88 \%(35 / 394)$ & 0.923 & 0.980 & 0.956 \\
\hline \multicolumn{7}{|c|}{ Gestation weeks at delivery (weeks),\%(n) } \\
\hline$<32$ & $0.75 \%(3 / 399)$ & $0.82 \%(17 / 2062)$ & $2.03 \%(8 / 394)$ & 0.589 & 0.038 & 0.112 \\
\hline $32-36$ & $5.01 \%(20 / 399)$ & $5.53 \%(114 / 2062)$ & $7.36 \%(29 / 394)$ & 0.401 & 0.113 & 0.126 \\
\hline$\geq 37$ & $94.24 \%(376 / 399)$ & $93.65 \%(1931 / 2062)$ & $90.61 \%(357 / 394)$ & 0.484 & 0.354 & 0.371 \\
\hline \multicolumn{7}{|l|}{ Child's sex, \%(n) } \\
\hline Male & $54.64 \%(218 / 399)$ & $54.51 \%(1124 / 2062)$ & $46.45 \%(183 / 394)$ & 0.507 & 0.053 & 0.104 \\
\hline Female & $45.36 \%(181 / 399)$ & $45.49 \%(938 / 2062)$ & $53.55 \%(211 / 394)$ & 0.511 & 0.085 & 0.101 \\
\hline \multicolumn{7}{|l|}{ Mode of delivery, $\%(n)$} \\
\hline Vaginal & $39.09 \%(156 / 399)$ & $34.58 \%(713 / 2062)$ & $23.35 \%(92 / 394)$ & 0.131 & 0.001 & $<0.001$ \\
\hline Cesarean section & $60.91 \%(243 / 399)$ & $65.42 \%(1349 / 2062)$ & $76.65 \%(302 / 394)$ & 0.223 & 0.033 & 0.022 \\
\hline
\end{tabular}

rising plasma levels of contrainsulin hormones such as cortisol or placental growth hormone [33]. Elevated glucose levels in mothers have also been found in some studies to be associated with higher rates of subclinical infections, potentially resulting in higher rates of chorioamnionitis [36]. Such subclinical infection are also linked with systemic inflammation, but can also be asymptomatic and result in instances of VPTD [36].

Among women undergoing FET, we observed no significant variation in congenital malformation rates as a function of BMI, which is largely consistent with work by Best et al. [37], who in a study of spontaneous conception observed no link between BMI and congenital deformity rates with the exception of an increase in cardiovascular malformations in underweight women. Unlike this past study, ours was among the first examining comparable outcomes in the context of a freeze-allbased FET approach. As our data regarding congenital defects came from patient questionnaires, there is a risk that any minor defects may have been overlooked, although this is unlikely to affect the overall study outcomes with respect to infant characteristics at birth.
Our study has several key strengths that lend the results credibility. For one, we had a large sample size and access to largely complete records with respect to the IVF protocols of enrolled patients, as well as detailed information on the resultant pregnancies and outcomes. As these results were collected from a single center, they also have the potential to be associated with a lower rate of heterogeneity than had they been derived from a broader multi-center study.

There are also several important limitations to this work. For one, as the study was retrospective in nature it is important that future randomized controlled trials validates the results discussed herein. Our results regarding overweight mothers was limited to results from a single group (BMI:25.0-29.9), whereas a larger dataset including obese (BMI 30.0-49.9) and superobese (BMI > 50) mothers may have provided additional insights. The weight and height of the patient was measured in the initial IVF/ICSI cycle. It took $6.05 \pm 5.21$ months from the measurement to the pregnancy occurred, which may affect the results. In addition, while we sought to control for as many confounding variables as possible, some 
Table 4 Incidence of birth defects in live-born infants and type of malformations according to the classification from code Q00-Q99 in the international classification of Disease,tenth editon

\begin{tabular}{|c|c|c|c|c|c|c|}
\hline Characteristics & $\begin{array}{l}\text { Underweight (< } 18.5 \\
\left.\mathrm{~kg} / \mathrm{m}^{2} \quad \mathrm{~N}=707\right)\end{array}$ & $\begin{array}{l}\text { Normal weight (18.5- } \\
\left.24.9 \mathrm{~kg} / \mathrm{m}^{2} \quad \mathrm{~N}=3663\right)\end{array}$ & $\begin{array}{l}\text { Overweight }(\geq 25 \\
\left.\mathrm{kg} / \mathrm{m}^{2} N=662\right)\end{array}$ & $\begin{array}{l}\text { Underweight vs. } \\
\text { normal weight }\end{array}$ & $\begin{array}{l}\text { Overweight vs. } \\
\text { normal weight }\end{array}$ & $\begin{array}{l}\text { Overweight vs } \\
\text { underweight }\end{array}$ \\
\hline $\begin{array}{l}\text { Number of birth defects, } \\
\%(n)\end{array}$ & $20(2.83 \%)$ & $66(1.81 \%)$ & $12(1.81 \%)$ & 0.058 & 0.541 & 0.151 \\
\hline Singletons & 12/399 (3.01\%) & 43/2061 (2.09\%) & 9/394 (2.28\%) & 0.175 & 0.462 & 0.347 \\
\hline Multiples & 8/308 (2.59\%) & 23/1602 (1.44\%) & $3 / 268(1.12 \%)$ & 0.117 & 0.478 & 0.168 \\
\hline \multicolumn{7}{|l|}{ Birth defects, by sex, $\%(n)$} \\
\hline Male & 13/378 (3.44\%) & 43/1956 (2.19\%) & $8 / 358$ (2.23\%) & 0.114 & 0.544 & 0.233 \\
\hline Female & $7 / 329(2.13 \%)$ & 23/1707 (1.35\%) & 4/304 (1.32\%) & 0.203 & 0.612 & 0.324 \\
\hline \multicolumn{7}{|l|}{ Detailed birth defects, $\%(n)$} \\
\hline $\begin{array}{l}\text { Q00-Q07 nervous } \\
\text { system }\end{array}$ & 0 & $2(0.05 \%)$ & 0 & 0.411 & 0.393 & / \\
\hline $\begin{array}{l}\text { Q10-Q18 eye, ear, } \\
\text { face, and neck }\end{array}$ & $2(0.28 \%)$ & $3(0.08 \%)$ & 0 & 0.187 & 0.486 & 0.525 \\
\hline $\begin{array}{l}\text { Q20-Q28 circulatory } \\
\text { system }\end{array}$ & $11(1.56 \%)$ & $36(0.98 \%)$ & $7(1.06 \%)$ & 0.129 & 0.495 & 0.289 \\
\hline $\begin{array}{l}\text { Q30-Q34 respiratory } \\
\text { system }\end{array}$ & 0 & $2(0.05 \%)$ & $1(0.15 \%)$ & 0.411 & 0.393 & 0.734 \\
\hline $\begin{array}{l}\text { Q35-Q37 cleft lip and } \\
\text { cleft palate }\end{array}$ & 0 & $4(0.11 \%)$ & 0 & 0.587 & 0.393 & / \\
\hline $\begin{array}{l}\text { Q38-Q45 digestive } \\
\text { system }\end{array}$ & 0 & $2(0.05 \%)$ & 0 & 0.411 & 0.393 & / \\
\hline $\begin{array}{l}\text { Q50-Q56 genital } \\
\text { organs }\end{array}$ & $2(0.10 \%)$ & $2(0.05 \%)$ & $1(0.15 \%)$ & 0.126 & 0.393 & 0.525 \\
\hline $\begin{array}{l}\text { Q60-Q64 urinary } \\
\text { system }\end{array}$ & $2(0.10 \%)$ & $5(0.14 \%)$ & $1(0.15 \%)$ & 0.317 & 0.631 & 0.525 \\
\hline $\begin{array}{l}\text { Q65-Q79 } \\
\text { musculoskeletal } \\
\text { system }\end{array}$ & $1(0.14 \%)$ & $1(0.03 \%)$ & $2(0.31 \%)$ & 0.298 & 0.063 & 0.476 \\
\hline $\begin{array}{l}\text { Q80-Q89 other } \\
\text { malformations }\end{array}$ & $1(0.14 \%)$ & $8(0.25 \%)$ & 0 & 0.559 & 0.589 & 0.734 \\
\hline $\begin{array}{l}\text { Q90-Q99 } \\
\text { chromosomal } \\
\text { abnormalities }\end{array}$ & $1(0.14 \%)$ & $1(0.03 \%)$ & 0 & 0.298 & 0.283 & 0.734 \\
\hline
\end{tabular}

Table 5 Adjusted ORs of pregnancy and neonatal outcomes

underweight vs. normal weight Adjusted Odds Ratio( $95 \% \mathrm{Cl})$

\begin{tabular}{ll}
\hline Clinical pregnancy & $0.75(0.66-0.94)$ \\
Miscarriage & $1.18(0.87-1.63)$ \\
Ongoing pregnancy & $0.80(0.64-0.95)$ \\
Live-birth & $0.63(0.20-2.29)$ \\
PTD & $0.93(0.80-1.12)$ \\
Very PTD & $1.09(0.97-1.24)$ \\
LBW & $1.16(0.87-1.56)$ \\
Very LBW & $1.08(0.92-1.33)$ \\
Small for gestational age & $1.11(0.79-1.60)$ \\
Very small for gestational age & $1.14(0.91-1.44)$
\end{tabular}

overweight vs. normal weight Adjusted Odds Ratio(95\% Cl)

$0.70(0.19-2.88)$

$1.62(1.21-2.36)$

$1.37(0.55-3.30)$

$0.94(0.77-1.12)$

$1.06(0.92-1.23)$

$1.51(1.09-2.23)$

$1.14(0.95-1.37)$

$1.50(1.38-1.51)$

$1.18(0.87-1.41)$

$1.63(1.40-1.78)$

PTD (preterm delivery: $<37$ weeks of gestation), very PTD (very preterm delivery: $<32$ weeks of gestation), LBW (low birth weight: birth weight $<2500 \mathrm{~g}$ );VLBW (very low birth weight: birth weight $<1500 \mathrm{~g}$ ). Analyses were adjusted for age of embryo transfer, age of oocyte retrieval, infertility duration, endometrial thickness, embryo quality, number of embryos transferred, and embryo developmental stage 
may have unintentionally still introduced bias into our study results. Further research is needed on the effects of pre-pregnancy maternal underweight on pregnancy/ perinatal outcomes following FET.

\section{Conclusions}

In summary, our results indicate that being underweight is linked to certain negative pregnancy/ perinatal outcomes for mothers undergoing FET. There is thus potential value in weight-related counseling not only for overweight women considering IVF, but also for those who are underweight in order to improve outcomes.

\section{Abbreviations}

BMI: Body mass index; FET: Frozen-thawed embryo transfer; IVF: In vitro fertilization; ART: Assisted reproductive technology; FSH: Follicle stimulating hormone; LH: Luteinizing hormone; E2: Estradiol; OR: Odds ratio; $\mathrm{Cl}$ : Confidence interval; PTD: Preterm delivery; VPTD: Very preterm delivery; LBW: Low birth weight; VLBW: Very low birthweight; PCOS: Polycystic ovary syndrome

\section{Acknowledgements}

We gratefully acknowledge all the staff of the department of assisted reproduction in Shanghai Ninth People's Hospital for their cooperation and support.

\section{Authors' contributions}

All the authors contributed to the conception and design of the study. ST, $\mathrm{JH}$ and $\mathrm{J} \mathrm{L}$ were responsible for data collection, data analysis, interpretation and manuscript drafting. $J \mathrm{~L}$ and $\mathrm{YK}$ were responsible for revising the article and supervising the project administration. All authors read and approved the final version of the article.

\section{Funding}

This study was funded by the National Key Research and Development Program of China (2018YFC1003000) and Special Plan for Shanghai Women's Health Service Capacity Building (2016-2020) (FNZX0901). The Funder had no role in the design, conduct or interpretation of the study. The open access publication fee is paid by the funder.

\section{Availability of data and materials}

The data used and analyzed during the study are available from the corresponding author if the request is reasonable.

\section{Ethics approval and consent to participate}

This study was approved by the Ethics Committee (Institutional Review Board) of Shanghai Ninth People's Hospital to access the data used in our research.

\section{Consent for publication}

Not applicable.

\section{Competing interests}

We declare that we do not have any commercial or associative interest that represents a conflict of interest in connection with the work submitted.

Received: 17 September 2020 Accepted: 21 December 2020 Published online: 07 January 2021

\section{References}

1. Rich-Edwards JW, Spiegelman D, Garland M, Hertzmark E, Hunter DJ, Colditz GA, et al. Physical activity, body mass index, and ovulatory disorder infertility. Epidemiology. 2002;13(2):184-90.

2. Talmor A, Dunphy B. Female obesity and infertility. Best Pract Res Clin Obstet Gynaecol. 2015;29(4):498-506.

3. Caillon H, Fréour T, Bach-Ngohou K, Colombel A, Denis MG, Barrière P, et al. Effects of female increased body mass index on in vitro fertilization cycles outcome. Obes Res Clin Pract. 2015;9(4):382-8.
4. Martinuzzi K, Ryan S, Luna M, Copperman AB. Elevated body mass index (BMI) does not adversely affect in vitro fertilization outcome in young women. J Assist Reprod Genet. 2008;25(5):169-75.

5. Zhang JJ, Feret M, Chang L, Yang M, Merhi Z. Obesity adversely impacts the number and maturity of oocytes in conventional IVF not in minimal stimulation IVF. Gynecol Endocrinol. 2015;31(5):409-13.

6. Dickey RP, Xiong X, Gee RE, Pridjian G. Effect of maternal height and weight on risk of preterm birth in singleton and twin births resulting from invitro fertilization: a retrospective cohort study using the Society for Assisted Reproductive Technology Clinic Outcome Reporting System. Fertil Steril. 2012;97(2):349-54.

7. Wei YM, Yang HX, Zhu WW, Liu XY, Meng WY, Wang YQ, et al. Risk of adverse pregnancy outcomes stratified for pre-pregnancy body mass index. J Matern Fetal Med. 2016;29(13):5.

8. Vivian R, Srividya S, Sunkara SK, Sviatlana S, Eugene ON, Tarek ET. Effect of body mass index on IVF treatment outcome: an updated systematic review and meta-analysis. Reprod BioMed Online. 2011;23(4):490-9.

9. Dechaud H, Anahory T, Reyftmann L, Loup V, Hamamah S, Hedon B. Obesity does not adversely affect results in patients who are undergoing in vitro fertilization and embryo transfer. Eur J Obstet Gynecol Reprod Biol. 2006; 127(1):88-93.

10. Vuong LN, Dang VQ, Ho TM, Huynh BG, Ha DT, Pham TD, et al. IVF transfer of fresh or frozen embryos in women without polycystic ovaries. N Engl J Med. 2018;378(2):137-47.

11. Roque M, Valle M, Guimarães F, Sampaio M, Geber S. Freeze-all policy: fresh vs. frozen-thawed embryo transfer. Fertil Steril. 2015;103(5):1190-3.

12. Cai J, Liu L, Zhang J, Qiu H, Jiang X, Li P, et al. Low body mass index compromises live birth rate in fresh transfer in vitro fertilization cycles: a retrospective study in a Chinese population. Fertil Steril. 2017;107(2):422429. e2.

13. Kuang Y, Chen Q, Fu Y, Wang Y, Hong Q, Lyu Q, et al. Medroxyprogesterone acetate is an effective oral alternative for preventing premature luteinizing hormone surges in women undergoing controlled ovarian hyperstimulation for in vitro fertilization. Fertil Steril. 2015;104(1):6270. e3.

14. Cummins J, Breen T, Harrison K, Shaw J, Wilson L, Hennessey J. A formula for scoring human embryo growth rates in in vitro fertilization: its value in predicting pregnancy and in comparison with visual estimates of embryo quality. J In Vitro Fert Embryo Transf. 1986;3(5):284-95.

15. Dai L, Deng C, Li Y, Zhu J, Mu Y, Deng Y, et al. Birth weight reference percentiles for Chinese. PLoS One. 2014;9(8):e104779.

16. Innes K, Hooper J, Bramley M, Dahdah P. Creation of a clinical classification. International statistical classification of diseases and related health problems--10th revision, Australian modification (ICD-10-AM). Health Inf Manag. 1997;27(1):31-8.

17. Wang $X$, Hao J, Zhang F, Li J, Kong H, Guo Y. Effects of female and male body mass indices on the treatment outcomes and neonatal birth weights associated with in vitro fertilization/intracytoplasmic sperm injection treatment in China. Fertil Steril. 2016;106(2):460-6.

18. Kawwass JF, Kulkarni AD, Hipp HS, Crawford S, Kissin DM, Jamieson DJ. Extremities of body mass index and their association with pregnancy outcomes in women undergoing in vitro fertilization in the United States. Fertil Steril. 2016;106(7):S0015028216627255.

19. Cai J, Liu L, Zhang J, Qiu H, Jiang X, Li P, et al. Low body mass index compromises live birth rate in fresh transfer in vitro fertilization cycles: a retrospective study in a Chinese population. Fertil Steril. 2016;107(2):422.

20. Pinborg A, Gaarslev C, Hougaard CO, Andersen AN, Andersen PK, Boivin J, et al. Influence of female bodyweight on IVF outcome: a longitudinal multicentre cohort study of 487 infertile couples. Reprod BioMed Online. 2011;23(4):401-2.

21. Veleva Z, Tiitinen A, Vilska S, Hyden-Granskog C, Tomas C, Martikainen H, et al. High and low BMI increase the risk of miscarriage after IVF/ICSI and FET. Hum Reprod. 2008;23(4):878-84.

22. Mitchell M, Armstrong DT, Robker RL, Norman RJ. Adipokines: implications for female fertility and obesity. Reproduction. 2005;130(5):583-97.

23. Iversen PO, Drevon CA, Reseland JE. Prevention of leptin binding to its receptor suppresses rat leukemic cell growth by inhibiting angiogenesis. Blood. 2002:100(12):4123-8.

24. Cervero A, Horcajadas JA, Martin J, Pellicer A, Simón C. The leptin system during human endometrial receptivity and preimplantation development. J Clin Endocrinol Metab. 2004;89(5):2442-51. 
25. Branum AM, Schoendorf KC. Changing patterns of low birthweight and preterm birth in the United States, 1981-98. Paediatr Perinat Epidemiol. 2010;16(1):8-15,

26. Sharifzadeh F, Kashanian M, Jouhari S, Sheikhansari N. Relationship between pre-pregnancy maternal BMI with spontaneous preterm delivery and birth weight. J Obstet Gynaecol. 2015;35(4):354-7.

27. Lynch AM, Hart JE, Agwu OC, Fisher BM, West NA, Gibbs RS. Association of extremes of prepregnancy BMI with the clinical presentations of preterm birth. Am J Obstet Gynaecol. 2014;210(5):428.e1-e9.

28. Sazonova A, Källen K, Thurin-Kjellberg A, Wennerholm U-B, Bergh C. Obstetric outcome in singletons after in vitro fertilization with cryopreserved/thawed embryos. Hum Reprod. 2012;27(5):1343-50.

29. Wang YA, Sullivan EA, Black D, Dean J, Bryant J, Chapman M. Preterm birth and low birth weight after assisted reproductive technology-related pregnancy in Australia between 1996 and 2000. Fertil Steril. 2005;83(6): $1650-8$.

30. Shih W, Rushford DD, Bourne H, Garrett C, Mcbain JC, Healy DL, et al. Factors affecting low birthweight after assisted reproduction technology: difference between transfer of fresh and cryopreserved embryos suggests an adverse effect of oocyte collection. Hum Reprod. 2008;23(7):1644-53.

31. Cnattingius S, Bergström R, Lipworth L, Kramer MS. Prepregnancy weight and the risk of adverse pregnancy outcomes. N Engl J Med. 1998;338(3):147.

32. Willson KJ, Rumbold AR, Chaturica A, Crowther CA. The risk of adverse pregnancy outcomes in women who are overweight or obese. BMC Pregnancy Child. 2010;10(1):1-8.

33. Luke B. Adverse effects of female obesity and interaction with race on reproductive potential. Fertil Steril. 2017;107(4):868.

34. Hak AE, Stehouwer CD, Bots ML, Polderman KH, Schalkwijk CG, Westendorp IC, et al. Associations of C-reactive protein with measures of obesity, insulin resistance, and subclinical atherosclerosis in healthy, middle-aged women. Arterioscler Thromb Vasc Biol. 1999;19(8):1986-91.

35. Pickup JC, Mattock MB, Chusney GD, Burt D. NIDDM as a disease of the innate immune system: association of acute-phase reactants and interleukin-6 with metabolic syndrome X. Diabetologia. 1997;40(11):1286.

36. Scholl TO, Sowers MF, Chen X, Lenders C. Maternal glucose concentration influences Fetal growth, gestation, and pregnancy complications. Am J Epidemiol. 2001:154(6):514-20.

37. Best $\mathrm{K}$, Tennant $\mathrm{P}$, Bell R, Rankin J. Impact of maternal body mass index on the antenatal detection of congenital anomalies. BJOG. 2012;119(12):150311.

\section{Publisher's Note}

Springer Nature remains neutral with regard to jurisdictional claims in published maps and institutional affiliations.

Ready to submit your research? Choose BMC and benefit from:

- fast, convenient online submission

- thorough peer review by experienced researchers in your field

- rapid publication on acceptance

- support for research data, including large and complex data types

- gold Open Access which fosters wider collaboration and increased citations

- maximum visibility for your research: over $100 \mathrm{M}$ website views per year

At $\mathrm{BMC}$, research is always in progress.

Learn more biomedcentral.com/submissions 